\title{
IMPACT OF CUSTOMER SATISFACTION ON FINANCIAL RESULTS OF CAR SERVICING COMPANIES: FINDINGS FROM SLOVENIA
}

\author{
Aleš Novak, Petra Šparl, Slavko Ažman
}

\section{Introduction}

Trends of globalization of the world economy are opening up many new opportunities for the companies. At the same time globalisation is increasingly wiping out local monopolies and exposing individual companies to international competition. Many companies have therefore difficulties to compete in such an environment, especially if they are using primarily price or technology as their competitive advantage. Consequently, business strategies emphasising quality should be quite appropriate for these companies [18]. Due to this reason more and more companies are paying increased attention to quality and customer satisfaction. According to widely accepted disconfirmation paradigm, satisfaction arises, if a considerable discrepancy (positive and/or negative) between expectations and perceptions occurs [5], [17], [38]; in [39]. Nevertheless, expectations, perceptions as well as resulting customer satisfaction are not static but dynamic variables. Other authors [30] [19] argue that it is a cumulative construct that is affected by market expectations and performance perception in any given period and is affected by past satisfaction from period to period [32].

The majority of large and medium-sized companies regularly measure customer satisfaction [10]. This also applies to the personal vehicle servicing companies (henceforth car servicing companies). The measurement of customer satisfaction in this industry is usually prescribed by the car manufacturers. According to [9] the car after-sales sector, long after the customer has taken delivery of the car, represents a mean of continuous contact between the car manufacturers and the customers, which is important for achieving greater car brand loyalty among customers.
Car manufacturers in collaboration with the national importers often seek to improve customer satisfaction with the car after-sales services through a system of bonuses that are applicable for the original spare part purchases by the car servicing companies. These financial bonuses are dependent on the results of the regular measurement of customer satisfaction with car after-sales services.

For the purpose of this paper we define aftersales services according to [9] as "all activities geared towards maintaining the quality and reliability of the car carried out after the customer has taken delivery with the goal of ensuring customer satisfaction". Maintenance and repair services are typically the most important aftersales services. In our paper we also consistently use the term "car servicing company". As this type of companies are usually providing not only after-sales services but also sell new and used cars at the retail level, they could be alternatively labelled as "car dealerships". But since the paper focuses exclusively on the above defined aftersales segment of such a business, we decided to use the term "car servicing company".

Similar to other industries it is considered obvious also for this industry that higher customer satisfaction leads to better financial results (financial performance, profitability) at least in a long run.

The purpose of this study is to determine whether there is an empirical evidence of a direct relationship between the customer satisfaction and financial results of the companies in the car servicing industry in Slovenia.

The relationship between customer satisfaction and financial results of the companies is theoretically grounded on the concept of service profit chain [16], which is presented in Figure 1. 


\section{Fig. 1: Service profit chain}

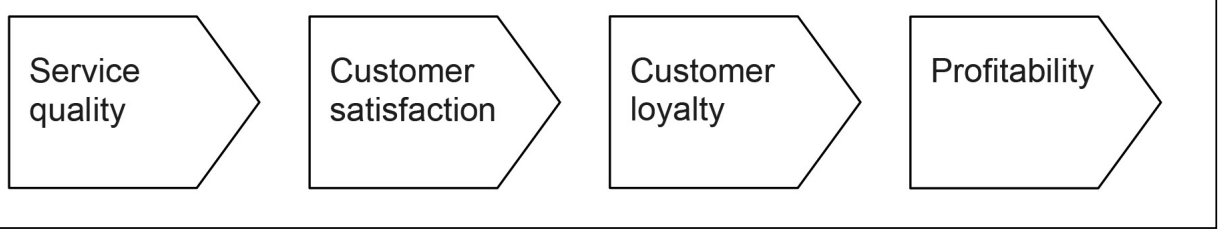

Source: [16]

The concept of the service profit chain assumes that it is possible to positively influence customer satisfaction by increasing the quality of the individual service elements, which in turn leads to better financial results through the increased customer loyalty.

Quality of any service depends on many factors. These include the qualification of personnel involved in its delivery, the process of interaction with the client, and of course the final result that is delivered [13].

Two relevant indicators influence customer satisfaction: on one hand the quality of the respective products or services (product/ service quality), on the other hand the quality of perceived customer relationship management measures (relationship management quality), which are used during the individual phases of the customer relationship life cycle. Therefore the product/service satisfaction and the relationship management satisfaction can be distinguished [39]. In our paper we focus on service customer satisfaction.

Since the original formulation of the service profit chain in 1994, different aspects of these relationships have been researched [22], [27], [37], [4] and [44].

The crucial role of the customer loyalty in transforming the customer satisfaction into profitability was also confirmed by a longitudinal study, performed by [14]. Their study showed that the satisfaction creates shareholder value by increasing future cash flow growth and reducing its variability. [31] complement and extend that study by showing that customer satisfaction has an impact on firm value, which is over and above the impact of profit (earnings). They find that firm value is influenced by profit, customer satisfaction and the interaction between these two metrics.
However, customer satisfaction does not affect profitability only through customer loyalty. Increased customer satisfaction is also reflected in lower costs, which otherwise arise because of poor quality of goods or services, such as the cost of warranty claims, product replacement, additional repairs and customer complaint processing. In addition, the recommendations of the satisfied and loyal customers reduce the new customer acquisition costs and enhance the overall reputation of the company [2].

[3] demonstrated that higher customer satisfaction decreases the price elasticity of demand as well as the possibility of switching to other service providers, even in the cases of temporarily reduced quality. [43] found that the price elasticity is actually the criterion that best distinguishes between the customers who are loyal and customers who are not loyal (stayers and defectors). This is also consistent with the studies performed by [35], [20] and [8] which found that the majority of the defectors leave because of the price issues.

Each relationship between the service profit chain elements has been empirically investigated; nevertheless it seems that the relationship between the customer satisfaction and financial results is the most problematic one.

It is worth pointing out that the link between increased customer satisfaction and increased profitability was confirmed by numerous studies. Literature review from this field, performed by [10], demonstrated that all scientific paper under examination advocated a positive impact of the increased customer satisfaction on (at least in the long term) business performance. Similar results could be found also in some recent papers [24], [26], [15] and [21].

On the other hand it is also possible to 
find different conclusions about this matter. Literature review on the relationship between the quality of the services and financial results [36] indicated that customer's evaluation of service quality and customer satisfaction are "sometimes, but not always" reflected in the financial results of the businesses.

[6] failed to demonstrate a statistically significant relationship between customer satisfaction and financial results despite dealing with the extremely large sample for an US chain of fast food restaurants. Instead they detected a relationship between the changes in customer satisfaction and the changes in financial results.

[33] were also not able to confirm the relationship between the customer satisfaction and customer loyalty and financial results of the company when they were trying to verify the concept of the service profit chain for a chain of "do-it-yourself" (DIY) stores in the United Kingdom.

It is also worth pointing out that some papers even demonstrated a negative relationship between the customer satisfaction and the financial results. Thus, for example, [40] found a negative correlation between the customer satisfaction and pre-tax profit. [42] also found a negative relationship between customer satisfaction and the return on investment for the companies in service-providing industries, while for the manufacturing businesses the relationship was actually positive.

In addition, research on the direct relationship between service quality and profits has shown both positive effects in a limited number of studies and no effects in other studies [45].

Growing body of research also suggests that the relationships between individual elements of the service profit chain are not linear. Most of the papers on the nonlinearity refer to the relationship between the service quality elements and the customer satisfaction and to the relationship between customer satisfaction and customer loyalty [3], [28], [2], [24], [7] and [11].

[2] demonstrated that the customer satisfaction had a diminishing impact on profitability (decreasing returns) and is therefore nonlinear.

Once a certain level of the customer satisfaction is reached, all improvements of the services and products that are necessary to further improve the customer satisfaction usually require increased investments. But at the same time the positive impact of these investments on reducing costs and increasing revenue decreases. This means that blindly investing in customer satisfaction may even adversely affect the company's financial results.

[24] noted that an optimal level of customer satisfaction exists. If this level of satisfaction is exceeded, the shareholder value is being destroyed. [41], who wrote that: "Customer satisfaction may have a positive effect on brand equity, except when managers show excessive customer orientation, and in this case the effect is negative, because of the reductions and the shareholder value", thus came to similar conclusions. [23] and [29] also warned of the negative effects of extremely customer oriented policies.

In the literature that examined the relationship between customer satisfaction and financial results two different types of satisfaction measures could be identified. Some papers used national customer satisfaction indices (e.g. the American Customer Satisfaction Index (ACSI): [24], [34] and [31]; the Swedish Customer Satisfaction Index (SCSI): [1] and [2]), while others relied on individual company customer satisfaction measurements.

At the same time the diversity of the financial result (financial performance, profitability) measures is even greater. For example, [42] used the return on assets, [1] return on investment, [12] stock returns, [24], [14] and [21] shareholder value and [40] pre-tax profit.

The remainder of the paper proceeds as follows. In Section 1 we discuss data characteristics and describe research design. Empirical tests and results are in Section 2. Section 3 contains a discussion and the last section of the paper contains Conclusions.

\section{Data and Research Design}

\subsection{Data}

The fundamental data for our research was the data on customer satisfaction with the car after-sales services in authorized car servicing network of five European automobile brands in Slovenia for the year 2009.

The data was collected in the computerassisted telephone survey, which involved 6,376 customers in 36 Slovenian car servicing companies of five European car brands in Slovenia. There are 48 such car servicing 
companies in Slovenia, but 12 were excluded from the analysis due to unavailability of the reliable financial information on only aftersales segment of those companies, separated from the sales of the new and used cars segments. The car servicing companies and their customers are coming from all Slovenian regions. Relevant demographic characteristics of survey respondents are presented in Table 1.

Vast majority of respondents were male $(75.2 \%)$, reflecting the actual customer gender structure of car servicing companies. Most respondents $(70 \%)$ were aged between 30 and 60 years. The majority of the serviced cars $(71.3 \%)$ were less than 7 years old. Moreover, $42 \%$ of them were no more than 4 years old. This is a reflection of the actual age structure of serviced cars, since older cars tend to be serviced outside of the official servicing network.

The questionnaire consisted of 50 questions, including four main questions: overall satisfaction with the service, willingness

\section{Tab. 1: Profile of respondents by age group, gender and age of cars}

\begin{tabular}{l|c|c} 
Profile of respondents and age of cars & & Share \\
\hline \multirow{4}{*}{$\begin{array}{l}\text { Respondent age group } \\
\text { (in years) }\end{array}$} & up to 30 & $16.2 \%$ \\
\cline { 2 - 3 } & $31-40$ & $24.8 \%$ \\
\cline { 2 - 3 } & $41-50$ & $25.0 \%$ \\
\cline { 2 - 3 } & $51-60$ & $20.2 \%$ \\
\cline { 2 - 3 } & over 60 & $13.7 \%$ \\
\hline \multirow{2}{*}{ Gender } & male & $74.8 \%$ \\
\hline \multirow{3}{*}{$\begin{array}{l}\text { Age of cars } \\
\text { (in years) }\end{array}$} & female & $25.2 \%$ \\
\cline { 2 - 3 } & up to 3 & $42.2 \%$ \\
\cline { 2 - 3 } & $4-6$ & $29.1 \%$ \\
\cline { 2 - 3 } & $7-9$ & $17.0 \%$ \\
\cline { 2 - 3 } & 10 and more & $11.6 \%$ \\
\hline
\end{tabular}

Source: own

to recommend the car servicing company to friends, intention of using the same car servicing company again (repurchase intention), perceived advantages of being a customer of the particular car servicing company, followed by 46 questions about satisfaction with individual phases or aspects of the car after-sales services. Questions on the satisfaction with the individual aspects of the services included, for example, satisfaction with the amiability of personnel, quality of the repair, waiting time, price-service ratio satisfaction etc.

Five-point Likert-type scale ranging from 1 (dissatisfied) to 5 (extremely satisfied) was used. Conversion of individual responses into numeric values is shown in Table 2 .

The questionnaire included also two questions about the car (year of manufacturing and type of ownership - private/corporate) and two questions about the respondent (gender and age). In addition, car servicing companies' financial information for the years 2009, 2010 and 2011 and data on the average hourly rates were obtained.

\subsection{Research Design}

Our main goal was to test the key hypothesis of our research, i.e. the fact that customer satisfaction has an impact on the financial results (financial performance, profitability) of the companies. It is worth pointing out that wider and more general meaning of the term "financial result" is used in our paper and not the very narrow meaning, which could be found in some accounting/finance textbooks, where 


\begin{tabular}{l|c}
\multicolumn{1}{c|}{ Answer } & Numerical value \\
\hline Dissatisfied & 1 \\
\hline Less satisfied & 2 \\
\hline Satisfied & 3 \\
\hline Very satisfied & 4 \\
\hline Extremely satisfied & 5 \\
\hline
\end{tabular}

the financial result is sometimes defined as the difference between earnings before interest and taxes and earnings before taxes, i.e. earnings which results from financial affairs. Since [6] argue that customer satisfaction influences financial results for a longer time period; we took into consideration also the time aspect of that influence.

As a first step we had to identify the most appropriate financial performance measures for our research. Since the mentioned Slovenian car servicing companies are not publicly traded companies (that offer their securities for sale to the general public, typically through stock exchange), we discarded all possible shareholder and stock exchange related financial ratios. In addition, we eliminated also the financial ratios which are based on the income statement information. Although the income statements of the car servicing companies are publicly available, they are not particularly useful for our research, because they provide condensed information for the car servicing company as a whole, combining the financial information on car after-sales services segment as well as the sales of the new and used cars segments (of course if they exist) of the business. The financial information that is relevant for our research should thus relate only to the car after-sales services segment of the car servicing company, so when the term car servicing company will be used henceforth it will actually imply only the car after-sales services segment of such a company. To enable more specific operations monitoring of authorised car servicing companies car manufacturers usually (indirectly through the authorised importers) prescribe certain granular structure of their business reports. The norm structure for the European car manufacturers is shown in Table 3.

The gross margin is the total revenue (gross sales revenue less sales returns and rebates) subtracted by the cost of goods sold. When providing after-sales services the cost of goods sold consist of mainly the cost of used materials and parts and direct labour expenses of trained automotive technicians. By subtracting different other expenses (see Tab. 3) different subtotals, i.e. contribution margins, are calculated. Other direct operating expenses refer to advertising \& marketing expenses and fleet vehicle expenses, while general and administrative expenses refer to energy and insurance expenses, consulting and other similar expenses and IT maintenance expenses. After subtracting also the fixed asset (plant, property and equipment, henceforth PPE) related expenses, which consist of depreciation and rental/lease expenses, the contribution margin 5 is obtained, which could also be labelled operating income or operating profit, because it is basically the total pre-tax profit that business generates from its operations. The profit or loss before tax (sometimes labelled also as earnings (income) before tax or even pre-tax profit) is the contribution margin 5 subtracted by the net financing expense (interest expense minus any interest income) and other operating expenses such as gains on disposal of PPE, paid damages, fines etc., which are in the USA often labelled as "extraordinary items".

In our paper we use two financial ratios as financial performance measures of the car servicing company. The first one is the pre-tax profit margin (PTPM), i.e. the car servicing company's earnings before tax as a percentage of total revenue, which is derived 


\section{Tab. 3: Approximate prescribed structure of the performance statement}

\section{Total revenue}

- cost of goods sold

= gross margin

- direct selling expenses

$=$ contribution margin 1

- other employee expenses

$=$ contribution margin 2

- other direct operating expenses

$=$ contribution margin 3

- general and administrative expenses

$=$ contribution margin 4

- fixed asset (PPE) related expenses

= contribution margin 5 (operating profit)

- net financing expense

- other (operating) expenses

\section{$=$ profit or loss before tax}

from dividing the profit or loss before tax by the total net revenue. The second one is the car servicing company's contribution margin 5 as a percentage of total revenue, which could also be labelled operating profit margin (OPM). The decision for the ratios instead of the monetary amounts was aimed to eliminate the impact of the car servicing company's size.

The following hypotheses were set up:

Hypothesis 1: Overall customer satisfaction with car after-sales services affects the operating profit margin of the car servicing company in the original year (2009) as well in the following two years (2010 and 2011).

Hypothesis 2: Overall customer satisfaction with car after-sales services affects the pre-tax profit margin of the car servicing company in the original year (2009) as well in the following two years (2010 and 2011).

Our analysis includes financial ratios as financial performance measures for the year, for which we have the data on customer satisfaction with car after-sales services (2009), for the following two years (2010 and 2011) and for the average of all three years (2009, 2010 and 2011). By that we wanted to examine possible lags and long-term effects.

Hypotheses 1 and 2 were tested by a series of simple linear regressions, where the overall customer satisfaction was an independent variable and each of the financial ratios for a certain year a dependent variable. Since the literature findings indicate contradictory customer satisfaction impact on financial results, we wanted to examine whether the influence is affected by the car servicing company's size. Therefore another hypothesis was set up:

Hypothesis 3: There are statistically significant differences regarding customer satisfaction influence on chosen financial ratios between the car servicing companies of various sizes.

For hypothesis 3 testing a series of simple linear regressions that were done for testing the hypotheses 1 and 2 were repeated, but separately for the group of small, medium and large-sized car servicing companies. Car servicing companies were classified into those 


\section{Tab. 4: Results of simple linear regressions for small-sized car servicing companies}

\begin{tabular}{c|c|c|}
\hline Financial ratio & \multicolumn{2}{|c|}{ SMALL-SIZED CAR SERVICING COMPANIES (N=7) } \\
\hline Dependent variable & Standardized beta & adjusted $\mathbf{R}^{\mathbf{2}}$ \\
\hline OPM-Service09 & -0.806 & 0.579 \\
\hline OPM-Service10 & $-0.894^{*}$ & $0.759^{\star}$ \\
\hline OPM-Service11 & $-0.941^{*}$ & $0.863^{*}$ \\
\hline OPM-Service09-11 & $-0.899^{*}$ & $0.770^{*}$ \\
\hline PTPM-Service09 & -0.756 & 0.486 \\
\hline PTPM-Service10 & -0.772 & 0.515 \\
\hline PTPM-Service11 & -0.748 & 0.472 \\
\hline PTPM-Service09-11 & -0.790 & 0.549 \\
\hline
\end{tabular}

Source: own

OPM = operating profit margin

PTPM = pre-tax profit margin

* Statistically significant at $p<0.01$.

three classes on the basis of their (car aftersales service segment) revenue. Car servicing companies with the (sales) revenue of less than $€ 250,000$ were classified to the smallsized class, in the medium-sized class with the revenue of more than $€ 250,000$ and less than $€ 500,000$ and in the large-sized class with the revenue of more than $€ 500,000$.

To test the lower price sensitivity of satisfied customers we established additional two hypotheses:

Hypothesis 4: Within car servicing companies with the below-average overall customer service satisfaction, the perceived price-service ratio depends on the hourly rate charged to the customer.

Hypothesis 5: Within car servicing companies with above-average overall customer service satisfaction, the perceived price-service ratio does not depend on the hourly rate charged to the customer.

For hypotheses 4 and 5 testing the car servicing companies were divided into two groups, i.e. into a group of car servicing companies with the below-average overall customer service satisfaction and the group with the above-average overall customer service satisfaction.

Hypothesis 4 was tested only for the group of car servicing companies with the belowaverage overall customer service satisfaction.
Within this group two subgroups were formed on the basis of the hourly rate charged to the customer. To test hypothesis 4 , we used an independent t-test of mean differences between the subgroup of car servicing companies with the above-average hourly rate charged to the customer and the subgroup of companies with the below-average hourly rate charged to the customer concerning the perceived priceservice ratio. Statistically significant differences would confirm the hypothesis 4 .

Hypothesis 5 was tested in the same way as the hypothesis 4 , but for the group of car servicing companies with the above-average overall customer service satisfaction. Note that in this case statistically insignificant differences would confirm the hypothesis 5 .

\section{Results}

First of all we made a series of simple linear regressions, with overall customer satisfaction as an independent variable and with several financial ratios for each year (2009, 2010 and 2011) as dependent variables. The results of all linear regressions were statistically insignificant $(p>0.05)$. Therefore, at significance level $p=0.05$ we could not confirm neither hypothesis 1, stating: "Overall customer satisfaction with car after-sales services affects the operating profit margin of the car servicing companies in the original year (2009) as well in the following 
two years (2010 and 2011)", nor hypothesis 2, stating: "Overall customer satisfaction with car after-sales services affects the pre-tax profit margin of the car servicing companies in the original year (2009) as well in the two following years (2010 and 2011)".

For testing hypothesis 3, stating: "There are statistically significant differences regarding customer satisfaction influence on chosen financial ratios between the car servicing companies of various sizes", we performed separate simple linear regressions for groups of small, medium and large-sized car servicing companies. Statistically significant results $(p<0.05)$ of linear regressions for different sizes of car servicing companies are shown in tables 4,5 and 6 , respectively.

Table 4 shows that for the group of small-sized car servicing companies all linear regressions are statistically significant (at $p<0.05$ ) for both financial ratios and for all observed years. Absolute values of standardized beta coefficient are high in all cases. The negative beta signs indicate a high negative dependence in all cases, without any exceptions. Values of adjusted $R^{2}$ are also relatively high.

In the group of medium-sized car servicing companies the results of linear regressions for both financial ratios are not statistically significant $(p>0.05)$ in the year 2009 (Tab. 5).
For the next two years and for the average of the three years all coefficients are positive and absolute values of standardized beta coefficients are much smaller in comparison to beta values for small-sized car servicing companies. Similarly, the percentage of the explained variation (adjusted $R^{2}$ ) is also lower.

For large-sized car servicing companies the linear regression model for the year 2009 is not statistically significant $(p>0.05)$ for the ratio pre-tax profit margin (PTPM), while for the ratio operating profit margin (OPM) already the results for the first year (2009) indicate a strong positive dependence $(\beta=0.889)$ (Tab. 6). For other two years, as well as for the average of all three years, the standardized beta coefficients are high and positive. Correspondingly high is also the percentage of explained variance (adjusted $\mathrm{R}^{2}$ ) for all these cases.

It can be summarized that results are very different regarding the size of car servicing companies. Namely, for small-sized car servicing companies a strong negative influence of the overall customer satisfaction on financial ratios is demonstrated, for the medium-sized car servicing companies a moderate positive influence could be noticed, while for the large-sized car servicing companies a strong positive influence of the overall customer satisfaction on financial ratios exists. This confirms the hypothesis 3 .

\section{Tab. 5: Results of simple linear regressions for medium-sized car servicing companies}

\begin{tabular}{c|c|c}
\hline Financial ratio & \multicolumn{2}{|c}{ MEDIUM-SIZED CAR SERVICING COMPANIES (N=22) } \\
\hline Dependent variable & Standardized beta & adjusted $\mathbf{R}^{\mathbf{2}}$ \\
\hline OPM-Servis09 & n.s.s. & n.s.s. \\
\hline OPM-Servis10 & 0.524 & 0.239 \\
\hline OPM-Servis11 & 0.497 & 0.21 \\
\hline OPM-Servis09-11 & 0.419 & 0.134 \\
\hline PTPM-Servis09 & n.s.s. & n.s.s. \\
\hline PTPM-Servis10 & $0.568^{*}$ & $0.289^{*}$ \\
\hline PTPM-Servis11 & $0.535^{*}$ & $0.250^{*}$ \\
\hline PTPM-Servis09-11 & 0.481 & 0.193 \\
\hline
\end{tabular}

Values denoted by n.s.s. are not statistically significant $(p>0.05)$. 
Tab. 6: Results of simple linear regressions for large-sized car servicing companies

\begin{tabular}{c|c|c} 
Financial ratio & \multicolumn{2}{|c}{ LARGE-SIZED CAR SERVICING COMPANIES (N=7) } \\
\hline Dependent variable & Standardized beta & adjusted $\mathbf{R}^{\mathbf{2}}$ \\
\hline OPM-Servis09 & $0.889^{\star}$ & $0.749^{\star}$ \\
\hline OPM-Servis10 & 0.826 & 0.620 \\
\hline OPM-Servis11 & $0.889^{\star}$ & $0.748^{\star}$ \\
\hline OPM-Servis09-11 & $0.903^{*}$ & $0.778^{*}$ \\
\hline PTPM-Servis09 & n.s.s. & n.s.s. \\
\hline PTPM-Servis10 & 0.828 & 0.622 \\
\hline PTPM-Servis11 & 0.839 & 0.644 \\
\hline PTPM-Servis09-11 & 0.809 & 0.586 \\
\hline
\end{tabular}

Source: own

Values denoted by n.s.s. are not statistically significant $(p>0.05)$.

* Statistically significant at $p<0.01$.

To test the lower price sensitivity of satisfied customers and consecutively to test hypothesis 4, stating: "Within car servicing companies with the below-average overall customer service satisfaction, the perceived price-service ratio depends on the hourly rate charged to the customer"; we used an independent t-test of mean differences of the perceived price-service ratio.

Table 7 shows that for car servicing companies with less overall satisfied (belowaverage) customers the perceived price-service ratio is actually different, depending on different hourly rate charged to the customer. According to the t-test ( $t=3.25$ and $p=0.006)$ hypothesis 4 can be accepted.

Table 8 shows that for car servicing companies with more (above-average) satisfied customers hourly rate charged to the customers does not affect the perceived price-service ratio $(p=0.397)$.

Therefore, we can accept hypothesis 5, stating: "Within car servicing companies with the above-average overall customer service satisfaction, the perceived price-service ratio does not depend on the hourly rate charged to the customer."

\section{Tab. 7: Results of t-test for a group of car servicing companies with below-average overall customer satisfaction}

\begin{tabular}{l|c}
\multicolumn{2}{c}{ Average perceived price-service ratio } \\
\begin{tabular}{l|c}
\hline Car servicing companies with below-average hourly rate & 4.01 \\
\hline Car servicing companies with above-average hourly rate & 3.64 \\
\hline \multicolumn{1}{c}{ t-test } & 3.25 \\
\hline $\mathrm{t}$ & 17 \\
\hline $\mathrm{df}$ & 0.006 \\
\hline sig. & \\
\hline
\end{tabular}
\end{tabular}




\begin{tabular}{l|c}
\multicolumn{2}{c}{ Average perceived price-service ratio } \\
\begin{tabular}{l|c}
\hline Car servicing companies with below-average hourly rate & 4.18 \\
\hline Car servicing companies with above-average hourly rate & 4.02 \\
\hline \multicolumn{2}{c}{ t-test } \\
\hline $\mathrm{t}$ & 0.871 \\
\hline $\mathrm{df}$ & 15 \\
\hline sig. & 0.397
\end{tabular} \\
\hline
\end{tabular}

\section{Discussion}

Initially, it is quite surprising that it was not possible to demonstrate a statistically significant relationship between an overall customer satisfaction with car after-sales services and financial results for the sample of car servicing companies under examination (hypotheses 1 and 2), especially since in practice this relationship is taken for granted. But if we take into account that academic literature cannot provide a straightforward answer about this relationship, our finding is thus not that controversial.

This could be explained by variations in the relationship between overall customer satisfaction and financial results among three different size classes of car servicing companies (hypothesis 3), based on their after-sales revenue. For the small-sized car servicing companies (revenue of less than $€ 250,000)$ a strong negative influence of the overall customer satisfaction on financial ratios was demonstrated, for the medium-sized car servicing companies a moderate positive influence, and for the large-sized car servicing companies (revenue of more than $€ 500,000$ ) a strong positive influence of the overall customer satisfaction on financial ratios was demonstrated.

The results for the small-sized class of car servicing companies may at first come as a surprise, yet we can offer several reasons to explain a (strong) negative influence of the overall customer satisfaction on financial results.

For example, more servicing personnel should translate to less waiting time for customers, their ability to devote more time to providing advice to customers etc., which should lead to higher customer satisfaction. However, this comes hand in hand with lower capacity utilisation and higher labour costs, which are not that easily offset by higher revenue that should be derived from higher customer satisfaction. The same also applies to free loaner cars or free minor services such as car bulb replacement or especially lower hourly rates charged to the customer, which should improve customer satisfaction but at the same time have a negative short-term impact on financial results (in our case operating profit margin and pre-tax profit margin). [9] also point out that the perceived quality of car after-sales services is influenced directly by how long the customer must wait to have the needed product fitted to his car. For the car servicing company, profitability is affected by the number of products (for example parts, tyres, auto chemicals etc.) that needs to be stocked. More products in stock should translate to less waiting time for customers, but on the other hand lead to higher fixed costs and lower profitability and liquidity.

On the other hand, the results for both medium-sized and large-sized car servicing companies were more in line with our expectations, which were based on the service profit chain concept (see Fig. 1).

It seems that the relationship between the overall customer satisfaction and the operating profit margin as well as the pre-tax profit margin is largely dependent on the level of competition in the local environment. The 
Tab. 9: ANOVA - differences in average values of customer satisfaction among the three car servicing companies' size classes

\begin{tabular}{l|c|c|c|c|c} 
& $\begin{array}{c}\text { Sum of } \\
\text { Squares }\end{array}$ & df & Mean Square & F & Sig. \\
\hline Between Groups & 0.077 & 2 & 0.038 & 1.139 & 0.332 \\
\hline Within Groups & 1.109 & 33 & 0.034 & & \\
\hline Total & 1.186 & 35 & & & \\
\hline
\end{tabular}

Source: own

largest car servicing companies are located in Slovenian cities, where there is often more than one authorised car servicing company, and thus customers often have a choice. According to service profit chain, customer service satisfaction affects customer loyalty. Loyal customers are evidently less likely to change a car servicing company and are less susceptible to higher hourly rates. The test of hypothesis 5 actually confirmed lower price sensitivity of customers who provided above-average overall service satisfaction scores.

The results also suggest (similarly to the findings of [24]) that a certain optimal level of customer satisfaction exists and when this level of satisfaction is surpassed, the financial results actually do not improve any more. Moreover, they usually deteriorate.

With regard to the average level of customer satisfaction, there are no (statistically significant) differences among small-sized, medium-sized and large-sized car servicing companies (see Tab. 9).

However, reaching a certain level of customer satisfaction is relatively more cost intensive for smaller car servicing companies. For larger car servicing companies, it is easier to ensure that there is enough servicing personnel also during vacation periods and in case of sick leave absences. In contrast to small car servicing companies they can, due to the economy of scale, employ more specialised personnel. In addition, personnel in larger car servicing companies more frequently deal with irregular, exacting car repairs, which are then (also due to a higher level of specialisation) processed in a shorter time, with fewer errors and fewer additional repairs needed than in the smaller car servicing companies, all this leads to positive cost effects.

On the other hand, for smaller car servicing companies the potential effects of high customer satisfaction levels are quite limited. Smaller car servicing companies usually operate in a less competitive environment. When a customer is buying a car, he/she is usually willing to travel pretty far away to get a better price, and is thus quite mobile. In contrast, the customer mobility for car after-sales services is much lower, so even when customers are not very satisfied with the after-sales services, they seldom switch to competitor that is not reasonably close to their home. This is beneficial especially for smaller car servicing companies, which usually operate in smaller towns without any direct competition of other authorised car servicing companies of the same brand.

Therefore, it seems that the optimal level of customer satisfaction, after which financial results actually do not improve anymore, is lower for car servicing companies. Hence, we infer that the small-sized car servicing companies surpassed their optimal level of customer satisfaction, so increases of customer satisfaction led to deterioration of financial results (high negative dependence). Conversely, in our opinion, at the same average level of customer satisfaction (please note that there are no statistically significant differences between the small-sized, mediumsized and large-sized car servicing companies with regard to the average level of overall customer satisfaction), large-sized car servicing companies were far below their optimal level of customer satisfaction, so increases of customer satisfaction led to the improvement of financial results (strong positive dependence). For the 
medium-sized car servicing companies, we infer that at the same average level of customer satisfaction there were still below their optimal level of customer satisfaction, but not very far from it, so the increases of customer satisfaction still led to the improvement of financial results. However, those improvements were not as substantial as for the large-sized car servicing companies (moderate positive dependence).

\section{Conclusions}

On the basis of our research we can conclude that the service profit chain concept, where increased quality positively influences customer satisfaction, which in turn leads to better financial results through increased customer loyalty, is not applicable in all cases and has some limitations. For the authorized car servicing network of five European automobile brands in Slovenia, we demonstrated that there are significant differences among the three classes of car servicing companies, based on their after-sales revenue.

For the small-sized car servicing companies, it is relatively more cost intensive to reach a certain level of customer satisfaction, while on the other hand, the potential positive effects of higher customer satisfaction are usually due to the local monopolies in smaller towns pretty low. In those circumstances the customers are actually stuck with a local car servicing company, and hence there is no need to invest much into customer satisfaction improvements to retain the existing customers.

Bigger car servicing companies are usually located in cities, where there are often other authorised same brand car servicing companies. Hence, it is not that difficult for customers to switch to a different car servicing company if they become dissatisfied with the services. In those circumstances it makes sense to invest more into high customer satisfaction, because it leads to high customer loyalty. Loyal customers are namely less likely to change a car servicing company and are less susceptible to higher hourly rates. The latter was actually confirmed by the test of hypothesis 5 .

Therefore, the optimal level of customer satisfaction, after which financial results actually stop to improve, is lower for the small-sized car servicing companies than for the bigger ones. Consequently, at the same average level of customer satisfaction, there is a strong negative dependence between increases of customer satisfaction and financial results for the small-sized car servicing companies, and a positive dependence between those two for the medium-sized and large-sized car servicing companies, which is moderate for the former and very strong for the latter.

One of the most intriguing questions remaining involves the generalizability of the association between perceived service quality and financial results across contexts. Companies are quick to point out that unique or competitive situations in their industries lead to doubts about the validity of research in other contexts to apply to them. Balancing the research across contexts is a priority to substantiate the general relationship and will also answer questions posed by companies about their own contexts [45]. This study hence contributes to literature by providing insight on the association between service quality and financial results in the specific context of after-sales services in car servicing industry.

A limitation of our study is that it is based on one country and authorised car servicing companies of five car brands of a single prominent European car manufacturer. However, it is worth pointing out that the cars of these five car brands have more than $20 \%$ share in the population of the registered cars in Slovenia [25]. In addition, these five car brands are quite different, some of them being more low-cost, and some of them more exclusive, hence covering many price ranges.

\section{References}

[1] ANDERSON, E.W., FORNELL, C., LEHMANN, D.R. Customer satisfaction, market share, and profitability - findings from Sweden. Journal of Marketing. 1994, Vol. 58, Iss. 3, pp. 53-66. ISSN 0022-2429. DOI: $10.2307 / 1252310$.

[2] ANDERSON, E.W., MITTAL, V. Strengthening the satisfaction-profit chain. Journal of Service Research. 2000, Vol. 3, Iss. 2, pp. 107-121. ISSN 1094-6705. DOI: 10.1177/109467050032001.

[3] ANDERSON, E.W., SULLIVAN, M.W. The antecedents and consequences of customer satisfaction for firms. Marketing Science. 1993, Vol. 12, Iss. 2, pp. 125-143. ISSN 1526-548X. DOI: $10.1177 / 109467050032001$.

[4] BATT, R. Managing customer services: 
human resource practices, quit rates, and sales growth. Academy of Management Journal. 2002, Vol. 45, Iss. 3, pp. 587-597. ISSN 00014273. DOI: $10.2307 / 3069383$.

[5] BEARDEN, W.O., TEEL, J.E. Selected determinants of consumer satisfaction and complaint reports. Journal of Marketing Research. 1983, Vol. 20, Iss. 1, pp. 21-28. ISSN 1547-7193. DOI: 10.2307/3151408.

[6] BERNHARDT, K.L., DONTHU, N., KENNETT, P.A. A longitudinal analysis of satisfaction and profitability. Journal of Business Research. 2000, Vol. 47, Iss. 2, pp. 161-171. ISSN 0148-2963. DOI: 10.1016/ S0148-2963(98)00042-3.

[7] CHEUNG, C.M.K., LEE, M.K.O. User satisfaction with an internet-based portal: an asymmetric and nonlinear approach. Journal of the American Society for Information Science and Technology. 2009, Vol. 60, Iss. 1, pp. 111122. ISSN 1532-2890. DOI: 10.1002/asi.20946. [8] COlgATE, M., HEDGE, R. An investigation into the switching process in retail banking services. International Journal of Bank Marketing. 2001, Vol. 19, Iss. 5, pp. 201-212. ISSN 0265-2323. DOI: $10.1108 / 02652320110400888$.

[9] EHINLANWO, O.O., ZAIRI, M. Best practice in the car after-sale service: an empirical study of Ford, Toyota, Nissan and Fiat in Germany - Part 1. Business Process Re-engineering \& Management Journal. 1996, Vol. 2, Iss. 2, pp. 39-56. ISSN 1355-2503. DOI: $10.1108 / 14637159610123597$.

[10] EKLÖF, J.A., HACKL, P., WESTLUND, A. On measuring interactions between customer satisfaction and financial results. Total Quality Management. 1999, Vol. 10, Iss. $4 / 5$, pp. $514-522$. ISSN 1360-0613. DOI: 10.1080/0954412997479.

[11] FINN, A. Investigating the non-linear effects of e-service quality dimensions on customer satisfaction. Journal of Retailing and Consumer Services. 2011, Vol. 18, Iss. 1, pp. 27-37. ISSN 0969-6989. DOI: 10.1016/j. jretconser.2010.09.002.

[12] FORNELL, C., MITHAS, S., MORGESON, F.V. The economic and statistical significance of stock returns on customer satisfaction. Marketing Science. 2009, Vol. 28, Iss. 5, pp. 820-825. ISSN 1526-548X. DOI: 10.1287/ mksc. 1090.0505.

[13] GANZ, W. Strengthening the services sector - needs for action and research. In: SPATH,
D. and FÄHNRICH, K.-P. (Eds.). Advances in Services Innovations. Heidelberg: Springer Verlag, 2007. pp. 223-256. ISBN 978-3-54029860-1. DOI: 10.1007/978-3-540-29860-1_12.

[14] GRUCA, T.S., REGO, L.L. Customer satisfaction, cash flow and shareholder value. Journal of Marketing. 2005, Vol. 69, Iss. July, pp. 115-130. ISSN 1547-7185. DOI: 10.1509/ jmkg.69.3.115.66364.

[15] HART, C.W. Beating the market with customer satisfaction. Harvard Business Review. 2007, Vol. 85, Iss. 3, pp. 30-32. ISSN 0017-8012. [16] HESKETT, J.L., et al. Putting the service-profit chain to work. Harvard Business Review. 1994, Vol. 72, Iss. 2, pp. 164-174. ISSN 0017-8012.

[17] HOMBURG, C., GIERING, A., HENTSCHEL, F. Der Zusammenhang zwischen Kundenzufriedenheit und Kundenbindung. Die Betriebswirtschaft (DBW). 1999, Vol. 59, pp. 174-195. ISSN 0342-7064. DOI: 10.1007/9783-322-99714-2_4.

[18] HOROVITZ, J., PANAK, M.J. Za popolno kupčevo zadovoljstvo. Ljubljana: Založba Gospodarski vestnik, 1997. ISBN 86-7061-150-3. [19] JOHNSON, M.D., ANDERSON, E.W., FORNELL, C. Rational and adaptive performance expectations in a customer satisfaction framework. Journal of Consumer Research. 1995, Vol. 21, Iss. 4, pp. 695-707. ISSN 0093-5301. DOI: 10.1086/209428.

[20] KEAVENEY, S.M. Customer switching behavior in service industries: an exploratory study. Journal of Marketing. 1995, Vol. 59, Iss. April, pp. 71-82. ISSN 1547-7185. DOI: 10.2307/1252074.

[21] LI, Q. Exploring the relationship between customer-related measures and shareholder value. Social Behavior and Personality. 2010, Vol. 38, Iss. 5, pp. 647-656. ISSN 0301-2212. DOI: $10.2224 /$ sbp.2010.38.5.647.

[22] LOVEMAN, G.W. Employee satisfaction, customer loyalty, and financial performance: an empirical examination of the service profit chain in retail banking. Journal of Service Research. 1998, Vol. 1, Iss. 1, pp. 18-31. ISSN 1094-6705. DOI: $10.1177 / 109467059800100103$.

[23] LUK, C.L., et al. Stakeholder orientation and business performance: the case of service companies in China. Journal of International Marketing. 2005, Vol. 13, Iss. 1, pp. 89-110. ISSN 1069-031X. DOI: 10.1509/jimk.13.1.89.58536.

[24] MATZLER, K., et al. The asymmetric relationship between attribute-level performance and overall customer satisfaction: 
a reconsideration of the importanceperformance analysis. Industrial Marketing Management. 2004, Vol. 33, Iss. 4, pp. 271277. ISSN 0019-8501. DOI: 10.1016/S00198501(03)00055-5.

[25] MINISTRY OF INTERNAL AFFAIRS OF REPUBLIC OF SLOVENIA. Seznam registriranih vozil $v$ Republiki Sloveniji na dan [online]. Ministry of International Affairs of Republic of Slovenia, 2011-12-31 [cit. 2012-0518]. Available from: https://e-uprava.gov.si/euprava/emrvl.euprava.

[26] MITTAL, V., ANDERSON, E.W., SAYRAK, A., TADIKAMALLA, P. Dual emphasis and the long-term financial impact of customer satisfaction. Marketing Science. 2005, Vol. 24, Iss. 4, pp. 544-555. ISSN 0732-2399. DOI: 10.1287/mksc. 1050.0142 .

[27] MITTAL, V., KAMAKURA, W.A. Satisfaction, repurchase intent and repurchase behavior: investigating the moderating effect of customer characteristics. Journal of Marketing Research. 2001, Vol. 38, Iss. February, pp. 131-142. ISSN 0022-2437. DOI: 10.1509/jmkr.38.1.131.18832.

[28] MITTAL, V., ROSS, W., BALDASARE, P.M. The asymmetric impact of negative and positive attribute-level performance on overall satisfaction and repurchase intentions. Journal of Marketing. 1998, Vol. 62, Iss. 1, pp. 33-47. ISSN 0022-2429. DOI: 10.2307/1251801.

[29] MORGAN, N.A.,ANDERSON, E.W., MITTAL, V. Understanding firms' customer satisfaction information usage. Journal of Marketing. 2005, Vol. 69, Iss. July, pp. 131-151. ISSN 0022-2429. DOI: 10.1509/jmkg.69.3.131.66359.

[30] OLIVER, R.L. A cognitive model of the antecedents and consequences of satisfaction decisions. Journal of Marketing Research. 1980 , Vol. 17, Iss. 4, pp. 460-469. ISSN 00222437. DOI: $10.2307 / 3150499$.

[31] O'SULLIVAN, D., McCALLIG, J. Customer satisfaction, earnings and firm value. European Journal of Marketing. 2012, Vol. 46, Iss. 6, pp. 827-843. ISSN 0309-0566. DOI: $10.1108 / 03090561211214627$.

[32] PISNIK KORDA, A., SNOJ, B., ŽABKAR, $V$. Antecedents and outcomes of perceived service value: evidence from Slovenia. $E+M$ Ekonomie a Management. 2012, Vol. 15, Iss. 1, pp. 105-115. ISSN 1212-3609.

[33] PRITCHARD, M., SILVESTRO, R. Applying the service profit chain to analyse retail performance: the case of the managerial strait-jacket? International Journal of Service
Industry Management. 2005, Vol. 16, Iss. 4, pp. 337-356. ISSN 0956-4233. DOI: $10.1108 / 09564230510613997$.

[34] RAMASAMY, B., YEUNG, M. Customer satisfaction and the consumption function. Economics Research International. 2010, Article ID 202014, 5 p. ISSN 2090-2123. DOI: 10.1155/2010/202014.

[35] REICHHELD, F.F. Loyalty-based management. Harvard Business Review. 1993, Vol. 71, Iss. 2, pp. 64-73. ISSN 0017-8012.

[36] SCHNEIDER, B. Service quality and profits: can you have your cake and eat it too? Human Resource Planning. 1991, Vol. 14, Iss. 2, pp. 151-157. ISSN 0199-8986.

[37] SILVESTRO, R., CROSS, S. Applying the service profit chain in a retail environment: challenging the satisfaction mirror. International Journal of Service Industry Management. 2000, Vol. 11, Iss. 3, pp. 244-268. ISSN 0956-4233. DOI: 10.1108/09564230010340760.

[38] STAUSS, B. Kundenzufriedenheit. Marketing ZFP. 1999, Vol. 21, Iss. 1, pp. 5-24. ISSN 0344-1369.

[39] STRAUSS, B., GOUTHIER, M., SEDEL, W. Satisfaction measurement within the customer relationship life cycle. In: SPATH, D. and FÄHNRICH, K.-P. (Eds.). Advances in Services Innovations. Heidelberg: Springer Verlag, 2007. pp. 205-220. ISBN 978-3-54029860-1.

[40] TORNOW, W.W., WILEY, J.W. Service quality and management practices: a look at employee attitudes, customer satisfaction, and bottom-line consequences. Human Resource Planning. 1991, Iss. 14, pp. 105-115. ISSN 0199-8986.

[41] TORRES, A., TRIBO, J.A. Customer satisfaction and brand equity. Journal of Business Research. 2011, Vol. 64, Iss. 10, pp. 1089-1096. ISSN 0148-2963. DOI: 10.1016/j. jbusres.2010.12.001.

[42] WESTLUND, A., FORNELL, C. Customer satisfaction measurements and its relationship to productivity analysis. In: Proceedings of the 8th World Productivity Congress. 1993, Stockholm.

[43] WILLIAMS, P., NAUMANN, E. Customer satisfaction and business performance: a firmlevel analysis. Journal of Services Marketing. 2011, Vol. 25, Iss. 1, pp. 20-32. ISSN 08876045. DOI: $10.1108 / 08876041111107032$.

[44] YEE, R.W.Y., YEUNG, A.C.L., CHENG, T.C.E. The service-profit chain: an empirical 
analysis in high-contact service industries. International Journal of Production Economics. 2011, Vol. 130, Iss. 2, pp. 236-245. ISSN 09255273. DOI: 10.1016/j.ijpe.2011.01.001.

[45] ZEITHAML, V.A. Service quality, profitability, and the economic worth of customers: what we know and what we need to learn. Journal of the Academy of Marketing Science. 2000 , Vol. 28 , Iss. 1 , pp. $67-85$. ISSN 0092-0703. DOI: $10.1177 / 0092070300281007$.
Assoc. prof. Aleš Novak, Ph.D.

University of Maribor

Faculty of Organizational Sciences ales.novak@fov.uni-mb.si

Assoc. prof. Petra Šparl, Ph.D. University of Maribor Faculty of Organizational Sciences petra.sparl@fov.uni-mb.si

Slavko Ažman

University of Maribor

Faculty of Organizational Sciences Porsche Slovenija d.o.o. slavko.azman@porsche.si 


\section{Abstract}

\section{IMPACT OF CUSTOMER SATISFACTION ON FINANCIAL RESULTS OF CAR SERVICING COMPANIES: FINDINGS FROM SLOVENIA}

\section{Aleš Novak, Petra Šparl, Slavko Ažman}

In this study, we explore the applicability of a service profit chain concept for the authorized car servicing network of five European car brands in Slovenia. Under this concept, increased quality positively influences customer satisfaction, which in turn leads to better financial results through increased customer loyalty. We demonstrated that there are significant differences among the three size classes of car servicing companies. At the same average level of customer satisfaction, there is a strong negative dependence between increases of customer satisfaction and financial results for the small-sized car servicing companies, and a positive dependence between those two for the medium-sized and large-sized car servicing companies, which is moderate for the former and very strong for the latter. It seems that the relationship between the overall customer satisfaction and financial results is largely dependent on the level of competition in the local environment. Bigger car servicing companies are usually located in cities, where there are often other authorised same brand car servicing companies. Hence, it is not that difficult for customers to switch to a different car servicing company if they become dissatisfied with the services. In those circumstances it makes sense to invest more into high customer satisfaction, because it leads to high customer loyalty. Loyal customers are namely less likely to change a car servicing company and are less susceptible to higher hourly rates. The results also suggest that a certain optimal level of customer satisfaction exists and whe $n$ this level of satisfaction is surpassed, the financial results actually do not improve any more. Moreover, they usually deteriorate.

Key Words: After-sales service, car servicing company, customer satisfaction, financial results, Slovenia.

JEL Classification: L25, M31.

DOI: 10.15240/tul/001/2015-3-011 